\title{
Increases in Pig Major Acute-Phase Protein in Wasting Pigs Brought to the Abattoir
}

\author{
Hiromi YAMANE ${ }^{1)}$, Hiroaki KANOUCHI ${ }^{2}$, Goro ARIMIZU'), Takeshi OBI ${ }^{3) *}$ and Tatsuzo OKA ${ }^{4)}$ \\ ${ }^{1)}$ Chiran Meat Inspection Center, Kagoshima Prefecture, 2221-1 Minamibeppu, Chiran-cho, Kawanabe-gun, Kagoshima 891-0912, \\ ${ }^{2)}$ Department of Biochemistry, Kawasaki Medical School, 577 Matsushima, Kurashiki, Okayama 701-0192, ${ }^{3)}$ Department of Animal \\ Science, Faculty of Agriculture, University of the Ryukyus, Nishihara-cho, Okinawa 903-0213 and ${ }^{4)}$ Department of Veterinary \\ Physiology, Faculty of Agriculture, Kagoshima University, 1-21-24 Korimoto, Kagoshima 890-0034, Japan
}

(Received 21 September 2005/Accepted 17 January 2006)

ABSTRACT. Plasma proteins of wasting pigs were quantitatively and qualitatively compared with those of normal fattening pigs. Higher expression of a $120 \mathrm{kDa}$ protein was observed in the plasma of wasting pigs by SDS-PAGE. This protein was identified as pig major acute-phase protein (Pig-MAP) by proteomic analysis using two-dimensional electrophoresis and matrix-assisted laser desorption/ionization time-of-flight mass spectrometry. The plasma concentration of Pig-MAP in wasting pigs was 7-fold higher than that of normal ones. KEY WORDS: meat inspection, pig major acute-phase protein, wasting pig.

J. Vet. Med. Sci. 68(5): 511-513, 2006

In meat inspection, it is difficult to determine whether wasting pigs transported to the abattoir are suitable for food or not. Generally, we decide whether there is need for detail inspection, referring to the degree of wasting macroscopically, and if necessary, reserve its carcass with the name of a disease of intense edema. The level of fitness for food is examined mainly by the water content of the skeletal muscle, while considering the results of post-mortem inspection, the degree of wasting and meat quality. However, by reason of only wasting, we can't condemn meat under the Abattoir Law. According to circumstances, we have to determine its meat qualification leaving the cause of wasting obscure, since there is no accurate criterion to inspect wasting state. Therefore, development of a more effective method to assess meat qualification of wasting pigs is anticipated.

Acute phase proteins (APP) such as haptoglobin (Hp), serum amyloid A (SAA) and C-reactive protein (CRP), all of which are plasma proteins, increase following infection, inflammation or trauma. Quantification of their concentrations in plasma or serum can provide valuable diagnostic information for prognosis and monitoring disease $[2,10]$. Accordingly, estimation of APP during meat inspection has been suggested helpful in improving food safety [11]. However, for quantification of pig APP, there are no available assay systems which can be utilized as a routine biochemical test in meat inspection.

In the present study, we compared the plasma protein levels of wasting pigs with those of normal fattening pigs using electrophoresis and proteomic analysis, and identified a unique protein, pig major acute-phase protein (Pig-MAP), highly expressed protein in wasting pigs.

Results are expressed as means \pm SD. Statistical evaluation of the data was performed using the Student's $t$-test for unpaired observations. Values were considered significantly different when $\mathrm{P}$ was less than 0.05 .

\footnotetext{
* Correspondence to: OBi, T., Department of Animal Science, Faculty of Agriculture, University of the Ryukyus, Nishiharacho, Okinawa 701-0192, Japan.
}

Fifty-six wasting pigs were selected macroscopically from their appearance (severe weight and subcutaneous fat loss). Thirty normal pigs were selected at random. The mean weights of the carcasses without the head and viscus were $29.9 \pm 8.3 \mathrm{~kg}(\mathrm{n}=42)$ for wasting pigs and $72.8 \pm 4.1 \mathrm{~kg}$ $(\mathrm{n}=30)$ for normal pigs $(\mathrm{P}<0.01)$. During slaughter, blood samples were collected in tubes containing heparin, then plasma was separated from each sample by centrifugation (3000 rpm, $10 \mathrm{~min}$ ) and stored at $-80^{\circ} \mathrm{C}$ until use. Total plasma protein concentrations were measured with a refract meter as $7.71 \pm 1.00 \mathrm{~g} / \mathrm{d} l(\mathrm{n}=56)$ in wasting pigs and $7.49 \pm$ $0.36 \mathrm{~g} / \mathrm{d} l(\mathrm{n}=30)$ in normal pigs. There were no significant differences between these values.

SDS-PAGE was carried out in 10\% gels (ATTO Corporation) as described by Laemmli [6]. Each plasma sample was diluted 80-fold in sample buffer with 2-mercaptoethanol, heated at $100^{\circ} \mathrm{C}$ for $2 \mathrm{~min}$ and separated at a constant current of $50 \mathrm{~mA}$. After electrophoresis, the gels were stained with Coomassie brilliant blue R-250. A highly expressed protein with a molecular mass of $120 \mathrm{kDa}$ was observed in most wasting pig samples (over $80 \%$ of samples) (Fig. 1, arrow). Quantitative analysis of this protein was performed using an image scanner (FLA-5000, Fuji Film Co., Ltd.). Levels (arbitrary units) of this protein were $1187.6 \pm 714.6(\mathrm{n}=20)$ in wasting pigs and $173.2 \pm 115.5(\mathrm{n}=20)$ in normal pigs $(\mathrm{P}<0.01)$. The mean concentration of this protein in wasting pigs was 7-fold higher than that in the normal pigs (Fig. 2).

This protein was analyzed also by two-dimensional electrophoresis at a $\mathrm{pH}$ range of $3-10$. The targeted protein was observed at $\mathrm{pH}$ 7-7.5 and shown to have a molecular mass of $120 \mathrm{kDa}$ (Fig. 3, boxed). The targeted protein was excised from the gels, trypsinized, and analyzed with matrix-assisted laser desorption time-of-flight (MALDITOF) mass spectrometer (Voyager DE-Pro, Applied Biosystems, Tokyo). The instrument was set up as follows: acceleration voltage $20 \mathrm{kV}$, grid voltage $76 \%$, mirror voltage ratio $1.12, \mathrm{~N} 2$, number of laser shots 100 , acquisition mass range 500-5,000 Da, delay $125 \mathrm{~ns}$, and vacuum degree 
$4 \times 10^{-7}$ Torr. A list of the corrected mass peaks provided details for peptide mass fingerprinting (PMF). Proteins were identified in the NCBI database through PMF using the MS-Fit program in protein prospector (http://prospector.ucsf.edu). As a result, this protein was identified as PigMAP (ACCESSION AAB35319) [3], which was first discovered in 1994 [7] as an acute phase protein induced experimentally by subcutaneous turpentine injection.

The present study revealed that of all plasma proteins, Pig-MAP is remarkably responded in wasting pigs. This protein, which is also called porcine inter-alpha-trypsin inhibitor human-related protein (pig IHRP), is the porcine

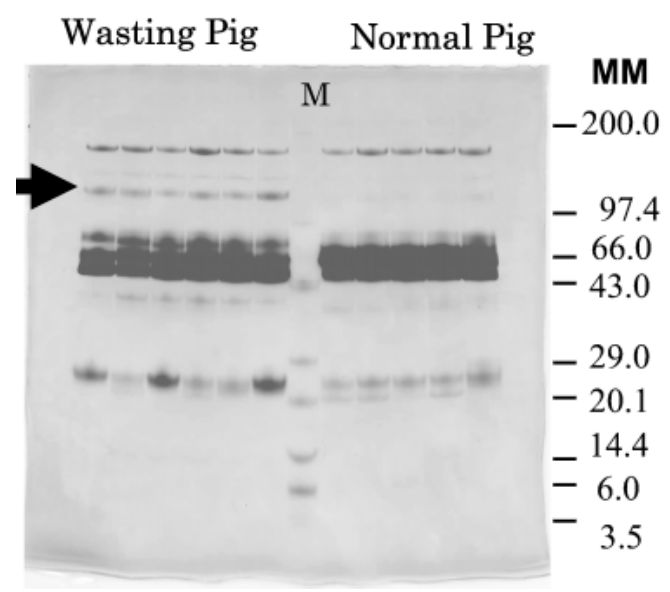

Fig. 1. SDS-PAGE of plasma protein from wasting (left) and normal (right) pigs. The band on the gel was visualized by CBB stain. MM represents molecular mass $(\mathrm{kDa})$. Molecular mass makers are applied to M lane. counterpart of human plasma kallikrein-sensitive protein (PK-120; also called human IHRP) [5]. The amino acid sequences obtained from pig, human, and rat proteins show significant homology with heavy chains $(\mathrm{H} 1, \mathrm{H} 2$ and $\mathrm{H} 3)$ of the inter-alpha-trypsin inhibitor (ITI) family [12]. PigMAP, human IHRP and the homologous rat protein have been designated ITIH4, a new member of the heavy chain ITI family [12]. However, since the physiological functions

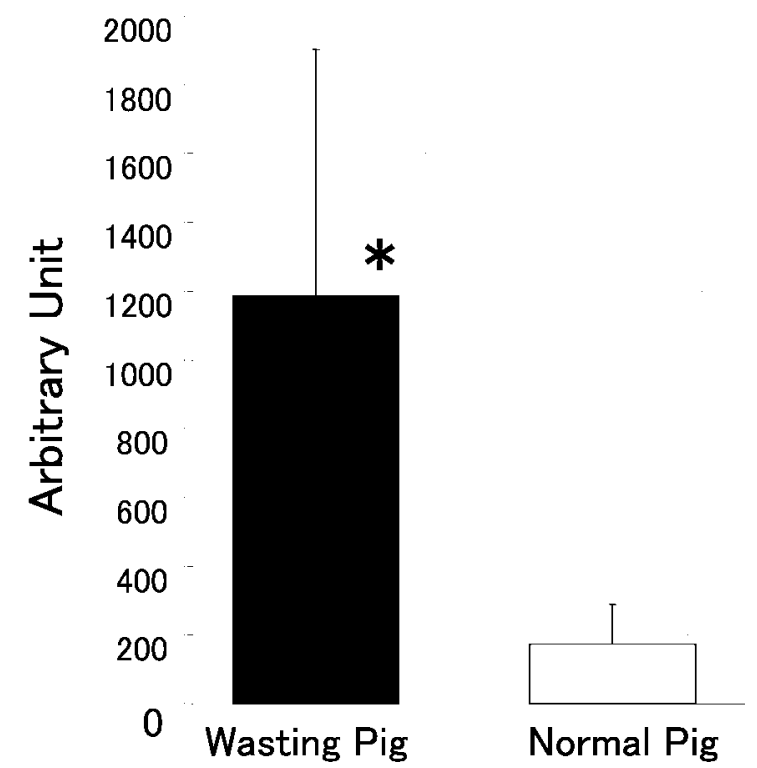

Fig. 2. Levels (arbitrary units) of pig-major acute protein from wasting (left) and normal (right) pigs. The band on the gel was quantified using image scanner. The results shown are the mean $\pm \mathrm{SD}$. *; significantly different from the value of normal pig $(\mathrm{P}<0.01)$.

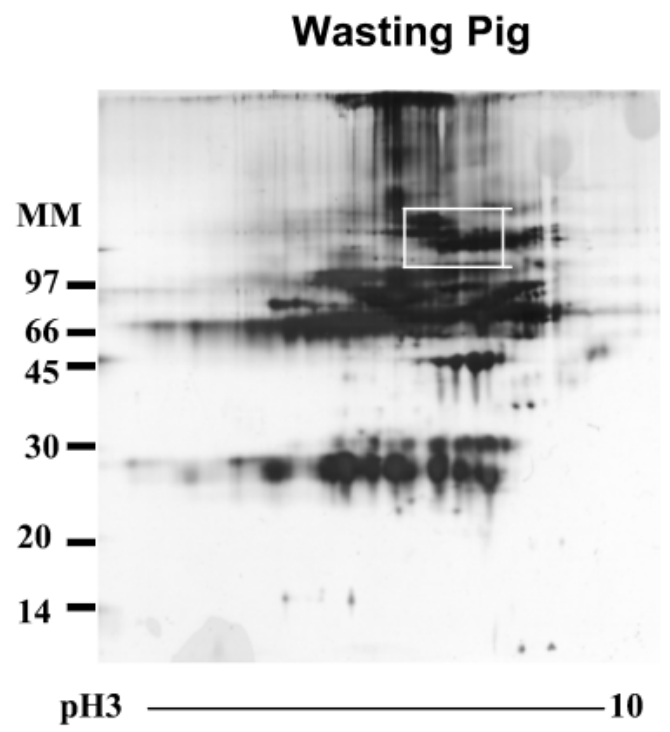

\section{Normal pig}

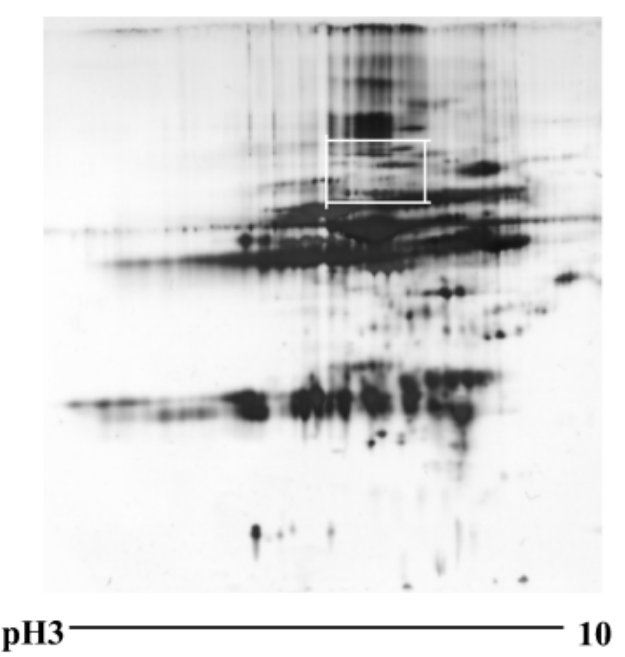

Fig. 3. Two-dimensional gel electrophoresis of the plasma protein from wasting (left) and normal (right) pigs. The spots on the gel were visualized by silver stain. MM represents molecular mass $(\mathrm{kDa})$. 
of ITI are not well defined yet, it is difficult to assess the implication of Pig-MAP in wasting pigs. Recent physiological studies suggest that human IHRP might act as an antiinflammatory protein since it inhibits actin polymerization and phagocytosis of polymorphonuclear cells [1]. Moreover, recent studies have reported that the serum concentration of Pig-MAP increases with experimental infection with Actinobacillus pleuropneumoniae [4] and postweaning multisystemic wasting syndrome [13]. Recently, ITIH4 was isolated also from cattle during experimental infection [10]. From these studies plus our results, Pig-MAP might provide an important marker for determining pig health status. Our results also suggested that something inflammatory existed in most wasting pigs.

In macroscopic post-mortem inspection in this study, we observed the following ratios in wasting pig and normal pig for respective disease: $66 \%$ and $43 \%$ for mycoplasmal pneumonia, $12 \%$ and $17 \%$ for pneumonia except mycoplasma, $14 \%$ and $10 \%$ for pleurisy, $6 \%$ and $3 \%$ for pericarditis, $27 \%$ and $23 \%$ for hepatitis, mainly vermiculose, $31 \%$ and $0 \%$ for enteritis, $2 \%$ and $0 \%$ for peritonitis and $20 \%$ and $0 \%$ for abscess formation including lung abscess. Enteritis and abscess formation were distinctive for wasting pigs compared to normal pigs, indicating the necessity for investigating the plasma of normal pigs acquiring these two diseases. On the other hand, interestingly, even in $8 \%$ of wasting pigs which were normal except for severe weight loss in the macroscopic post-mortem inspection, very high abundance of Pig-MAP on SDS-PAGE gel was recognized (data not shown). These results suggest that the assay of Pig-MAP assists meat inspector to identify hidden pathological lesions. The development of convenient methods for determining serum Pig-MAP concentration might become a useful tool at not only meat inspection centers but also at livestock hygiene service centers, thus improving overall food safety [8].

In conclusion, the serum Pig-MAP concentration of wasting pigs was 7-fold higher than that of normal pigs, suggesting that evaluation of Pig-MAP might be helpful in assessing the level of fitness of underdeveloped pigs. In line with this, further studies are needed to clarify the physiolog- ical functions of Pig-MAP.

ACKNOWLEDGEMENTS. The authors express their thanks to Yuko Kamimura, D.V.M., and Manabu Yamaguchi, D.V.M. of Kushikino Meat Inspection Center for supplying us with swine plasma. The authors are also grateful to Ms. Ayumi Fukuda, Mr. Hidekazu Shibano and Mr. Kouhei Kitsutaka for their valuable technical assistances.

\section{REFERENCES}

1. Choi-Miura, N. H., Takahashi, M., Yoda, M., Saito, K., Hori, M., Ozaki, H., Mazda, T. and Tomita, M. 2000. Inflamm. Res. 49: $305-310$.

2. Eckersall, P. D. 2000. Revue Med. Vet. 151: 577-584.

3. Gonzalez-Ramon, N, Alava, M. A., Sarsa, J. A., Pineiro, M., Escartin, A., Garcia-Gil, A., Lampreave, F. and Pineiro, A. 1995. FEBS Lett. 371: 227-230.

4. Heegaard, P. M. H., Klausen, J., Nielsen, J. P., GonzalezRamon, N., Pineiro, M., Lampreave, F. and Alava, M. A. 1998. Comp. Biochem. Physiol. B 119: 365-373.

5. Hashimoto, K., Tobe, T., Sumiya, J., Sano, Y., Choi-Miura, N.H., Ozawa, A., Yasue, H. and Tomita, M. 1996. J. Biochem. (Tokyo) 119: 577-584.

6. Laemmli, U. K. 1970. Nature (Lond.) 227: 680-685.

7. Lampreave, F., Gonzalez-Ramon, N., Martinez-Ayensa, S, Hernandez, M. A., Lorenzo, H. K., Garcia-Gil, A. and Pineiro, A. 1994. Electrophoresis 15: 672-676.

8. Lipperheide, C., Diepers, N., Lampreave, F., Alava, M. and Petersen, B. 1998. J. Vet. Med. A 45: 543-550.

9. Petersen, H. H., Nielsen, J. P. and Heegaard, P. M. H. 2004. Vet. Res. 35: 163-187.

10. Pineiro, M., Andres, M., Iturralde, M., Carmona, S., Hirvonen, J., Pyorala, S., Heegaard, P. M. H., Tjornehoj, K., Lampreave, F., Pineiro, A. and Alava, M. A. 2004. Infect. Immun. 72: 3777-3782.

11. Saini, P. K., Riaz, M., Webert, D. W., Eckersall, P. D., Young, C. R., Stanker, L. H., Chakrabarti, E. and Judkins, J. C. 1998. Am. J. Vet. Res. 59: 1101-1107.

12. Salier, J. P., Rouet, P., Raguenz, G. and Daveau, M. 1996. Biochem. J. 315: 1-9.

13. Segales, J., Pineiro, C., Lampreave, F., Nofrarias, M., Mateu, E., Calsamiglia, M., Andres, M., Morales, J., Pineiro, M. and Domingo, M. 2004. Vet. Res. 35: 275-282. 